抗癌剤および抗 androgen 剤による spermatogenesis

障害の実験的研究

札幌医科大学医学部泌尿器科学教室 (主任：熊本悦明教授)

南部 明民熊本 悦 明

\title{
STUDIES OF SPERMATOGENIC DAMAGES INDUCED BY ANTI-CANCER AGENT AND ANTI-ANDROGENIC AGENTS IN RAT TESTES
}

\author{
Akihito Nambu and Yoshiaki Kumamoto \\ Department of Urology, Sapporo Medical University, School of Medicine \\ (Chief: Prof. Y. Kumamoto)
}

To investigate the mechanisms responsible for and recovery process of spermatogenic damage induced by anti-cancer agent and anti-androgen agents, we experimented with rats injected with those agents.

Cis-diamminedichloroplatinum (CDDP) was selected as the anti-cancer agent causing spermatogenic damage. Flutamide and cyproterone acetate were selected as anti-androgen agents.

Both of these agents induced histopathological spermatogenic damage. The influences of CDDP on spermatogonia and spermatocytes were remakable, compared with cyproterone acetate and flutamide, which damaged mainly spermatids. CDDP had severely damaging effects on the DNA-synthesizing activity of spermatogenesis, based on findings using monoclonal antibody proliferating cell nuclear antigen (PCNA), compared with anti-androgen agents.

We also studied Sertoli cell function of drug-induced spermatogenic damage in rat testes. Measuring the contents of transferrin in rat testes indicated the damage to Sertoli cell function. High doses of CDDP $(8 \mathrm{mg} / \mathrm{kg})$ affected testicular transferrin concentration, but $4 \mathrm{mg} / \mathrm{kg}$ and 2 $\mathrm{mg} / \mathrm{kg}$ of CDDP had no significant effect on Sertoli cell function. Cyproterone acetate and flutamide had severely damaging effects on Sertoli cell function not only at a high dose $(30 \mathrm{mg} /$ $\mathrm{kg}$ ) but at low doses of $15 \mathrm{mg} / \mathrm{kg}$ and $7.5 \mathrm{mg} / \mathrm{kg}$.

These results showed that an anti-cancer agent primarily affects the DNA synthesizing activity of spermatogonia and spermatocytes, but high doses of these agents also have damaging effect on Sertoli cells, and anti-androgen agents mainly affect Sertoli cells.

Key words: spermatogenesis, DNA synthesizing activity, Sertoli cell

要旨：薬剤による spermatogenesis 障害の発現機構, および回復過程を検討する目的で, ラットの spermatogenesis に障害を与え, 精細管内の組織学的所見と, 抗 PCNA 抗体を用いた spermatogenesis の DNA 合成能, さらには精巣組織内 transferrin 濃度を指標とした Sertoli 細胞機能の関係について経時 的に検討した。

投与薬剤として，抗癌剤（CDDP） および抗 androgen 剤（cyproterone acetate, flutamide）を使用 した.

CDDP 投与群では, 組織学的検討には spermatogonia, spermatocyte の障害が顕著であり, 抗 androgen 剤投与群では spermatid の障害が顕著であった. DNA 合成能の評価では, CDDP 投与群で投与 量依存性の顕著な障害を示したのに対し, 抗 androgen 剤投与群ではそれぞれ $30 \mathrm{mg} / \mathrm{kg}$ の高投与量群の みで有意な障害が認められた. Sertoli 細胞機能の指標としての精巣組織中 transferrin 濃度の变化を見 
ると, 抗 androgen 剤投与群では, 低投与量群においても投与量依存性に Sertoli 細胞機能の障害が認め られていた。しかし CDDP 投与群では $8 \mathrm{mg} / \mathrm{kg}$ の高投与量群でのみ有意な低下を示していた。

今回の実験検討の結果から，CDDP においては DNA 合成能への障害が，抗 androgen 剂では Sertoli 細胞機能障害が，夫々主たる障害機構であるが，両薬剤とも高投与量になると，他の障害を合併し，よ り高度な障害を惹起することが明らかになった。

キーワード：spermatogenesis, DNA 合成能, Sertoli 細胞

\section{緒 言}

近年，癌治療学の進歩はめざましく，抗癌剤による 治療後の生存年数が著しく延長した疾患群がある. 泌 尿器科領域においては, 特に精巣腫瘍症例で, 患者の 生命予後は改善している ${ }^{1)}$. その結果, 症例が生殖年齢 に多いこともあり，副作用としての妊孕能の障害が浮 上し，臨床上の問題となっている233).

しかし，その抗癌剤による精子形成能（spermatogenesis）障害の詳細な検討は必ずしも充分とは 言えない点がある。そこで, 精巣腫瘍に対する化学療 法の主たる薬剤であるcis-diamminedichloroplatinum (以下 CDDP)の spermatogenesis 障害に ついて, 実験的に詳細に検討を試みた。同時に, spermatogenesis 障害を発症させる他の作用機序の薬剤と して, 抗 androgen 剤 (cyproterone acetate, flutamide) ${ }^{4) 5}$ での検討を行い, 抗癌剤と抗 androgen 剤との spermatogenesis 障害発症機序の相違点を分 析し, 抗癌剤による spermatogenesis 障害の特徵を検 討したので報告する.

\section{方法}

（1）実験動物および投与薬剤

実験動物として，8 週齢雄 Sprague-Dawley 系ラッ トを使用した. Spermatogenesis に障害を与える薬剤 として抗癌剤, および比較の目的で抗 androgen 剤を 用いた。

抗癌剤は, 精巣腫瘍に対する化学療法を想定し CDDPを用いた。投与量の設定は充分な spermatogenesis 障害を惹起し, かつラットの生存率を考 慮して, LD 50相当の $8 \mathrm{mg} / \mathrm{kg}$ 投与群を設定した. 薬剤 投与量と障害との関係を検討する目的で，そこから $1 /$ 2 量の $4 \mathrm{mg} / \mathrm{kg}$ 投与群および $1 / 4$ 量の $2 \mathrm{mg} / \mathrm{kg}$ 投与群を 設定した。

精巣腫瘍患者に対する多剤併用化学療法 (PVB) で の CDDP 投与量 $\left.20 \mathrm{mg} / \mathrm{m}^{2}{ }^{2}\right)$ は, ラットではおよそ 2.69 $\mathrm{mg} / \mathrm{kg}$ に相当する ${ }^{7)}$.

抗 androgen 剤としては, 中枢および末梢での抗 androgen 作用のある cyproterone acetate と, 主に末梢
での抗 androgen 作用を持つ flutamide を使用した. 抗 androgen 剤の投与量は CDDP 投与群と比較検討 するため, 組織学的に同じ程度の spermatogenesis 障 害度を示す投与量として, 基礎的検討の結果, 両薬剤 ともに $30 \mathrm{mg} / \mathrm{kg}$ とした.これは CDDP $8 \mathrm{mg} / \mathrm{kg}$ 投与 群での 2 週目での精巣組織所見 (total germinal cell index）とほほ同様の障害所見を示した投与量である. さらに各々 $1 / 2$ 量の $15 \mathrm{mg} / \mathrm{kg}$ 投与群, $1 / 4$ 量の $7.5 \mathrm{mg} /$ $\mathrm{kg}$ 投与群を設定した.

$\mathrm{CDDP}$ は生理食塩水 $1 \mathrm{ml}$ に溶解し, 腹腔内 1 回投与 とした。抗 androgen 剤は dimethyl-sulpho-oxside （DMSO）に溶解し， $1 \mathrm{ml}$ を腹腔内投与した.

各薬剂投与群で薬剤投与後それぞれ 2 週 (14日) 目, 4 週（28日）目，6週（42日）目，8週（56日）目， 10週（70日）目に両側精巣を摘出した。それぞれ精巣 摘出時点で各群 $\mathrm{n}=5$ となるようにラット数を調整し た。

また対照群として生理食塩水のみ $1 \mathrm{ml}$ を腹腔内投与 した群を薬剤投与前 $(n=12)$ および各週 $(n=5)$ で設 定した。この対照群間では以下に述べる各検討項目に は, 週数による有意な変動は認めなかった。経時的変 化を示すため, 対照群は薬剤投与前 ( 0 週) のみ示し た。

(2) Spermatogenesis の組織学的障害度の検討 摘出した精巣は, 片側はブアン液に固定後, パラフィ ン包埋し, $5 \mu \mathrm{m}$ の連続切片を作成した。 1 枚は hematoxylin-eosin 染色を行い, 光顕的に精細管を観 察した.ここで精細管内での各精細胞数（spermatogonia 数, spermatocyte 数, spermatid 数) を Sertoli 細胞数で除した数值を求めた.これをそれぞれ の精細胞の germinal cell index として組織学的な spermatogenesis の評価の指標とした ${ }^{8)}$.また各段階の germinal cell indexの合計を total germinal cell index とした。ささらに各精細胞の germinal cell index を結んだ曲線をグラフ化したものを spermatogenic curve $^{8)}$ とした (Fig. 5).

なお精細管は Leblond, Clermont ${ }^{8)}$ の stage 分類で 
I からVIIIまでの精細管を選択した。

精細管は割面において比較的円形に近い20精細管を 選び，その平均值で評価した。

(3) Spermatogenesisにおける DNA 合成能の評価 連続切片のもう一方は, 組織染色用に脱パラフィン 処置を行ったのちに，抗 proliferating cell nuclear antigen (PCNA) 抗体を用い, avidin-biotin peroxidase complex (ABC) 法による免疫組織染色を行っ た. 抗 PCNA 抗体で染色された精細胞数を, 同じ細管 内の Sertoli 細胞数で除した值の平均值をPCNA labeling index とし, spermatogenesis 過程における DNA 合成能を示す指標とした。抗 PCNA 抗体は DAKO 社製，また免疫組織染色はVector 社製 ABC キットを使用した。精細管は円形に近いものを 20 精細 管選択し，その平均で評価した。

（4）精巣組織内 transferrin 濃度の測定

摘出した他方の精巣は，白膜および肉眼的に観察さ れた血管を除去したのち mince した。さらに血球成分 の混入を除去するため PBS buffer で洗浄し， 1,500回 転，5分間遠沈した．遠沈後上清を捨て，再び洗浄， 遠沈し，この操作を 4 回繰り返した，光顕にて血球成 分の混入のないことを確認したのち, tritron homogenator $に て$ homogenate し，105,000g にて超 遠沈を加えた。そこで得られた上清を cytosol 分画と した.

Cytosol 分画中の transferrin 濃度は Skinner $ら^{10)}$ の方法に従って radio-immunoassay 2 抗体法にて測 定した.Cytosol 分画中の蛋白濃度は Bradford $の^{11}$ 方 法にて測定し，単位蛋白あたりの transferrin 濃度を
Sertoli 細胞機能の指標とした ${ }^{12)}$.

有意差の検定は，Mann-Whitney U 検定にて行っ た。有意水準は $\mathrm{p}<0.05$ とした。

\section{結 果}

（1）薬戍による spermatogenesis 障害時の精巣の 組織学的所見

対照群, CDDP $8 \mathrm{mg} / \mathrm{kg}$ 投与群, cyproterone acetate $30 \mathrm{mg} / \mathrm{kg}$ 投与群抒よび flutamide $30 \mathrm{mg} / \mathrm{kg}$ 投与 群でのそれぞれ 2 週目に抢ける精巣組織所見を Fig. 1 に示した。CDDP 投与群では対照群に比較して spermatogonia, spermatocyteの減少した精細管が多く観 察された. Cyproterone acetate 投与群, flutamide 投 与群では spermatid の脱落現象 (sloughing) を示す精 細管が多く観察された。

(1)-(a) CDDP 投与群における精巣の組織学的所 見

$\mathrm{CDDP} 8 \mathrm{mg} / \mathrm{kg}, 4 \mathrm{mg} / \mathrm{kg}$ および $2 \mathrm{mg} / \mathrm{kg}$ の 3 投与群 の投与後の total germinal cell index および spermatogonia, spermatocyte, spermatid の各精細胞そ れぞれの germinal cell index の推移を Fig. 2a，b，c にまとめた. 3 投与量群とも spermatogonia index, spermatocyte index, spermatid index 各々が，まず 平行移動する形で下降し，その後回復を示していた。 ただ spermatid indexは, spermatogonia index の最 低を示す 2 週目より，遅れて 4 週目に最低值となって いた. Spermatid indexの 4 週目の低下度は薬剤投与 量に依存的であった。

CDDP $2 \mathrm{mg} / \mathrm{kg}$ の低投与量群では， 2 週目で spermatid index の低下は軽度であったが, spermatocyte

Fig. 1 Histopathological appearance from rat testis administrated saline (a), CDDP $8 \mathrm{mg} / \mathrm{kg}$

(b), cyproterone acetate $30 \mathrm{mg} / \mathrm{kg}$ (c) and flutamide $30 \mathrm{mg} / \mathrm{kg}$, (d), injected after 2 weeks.

Fig. 2a Effect of CDDP $8 \mathrm{mg} / \mathrm{kg}$ on germinal cell index.

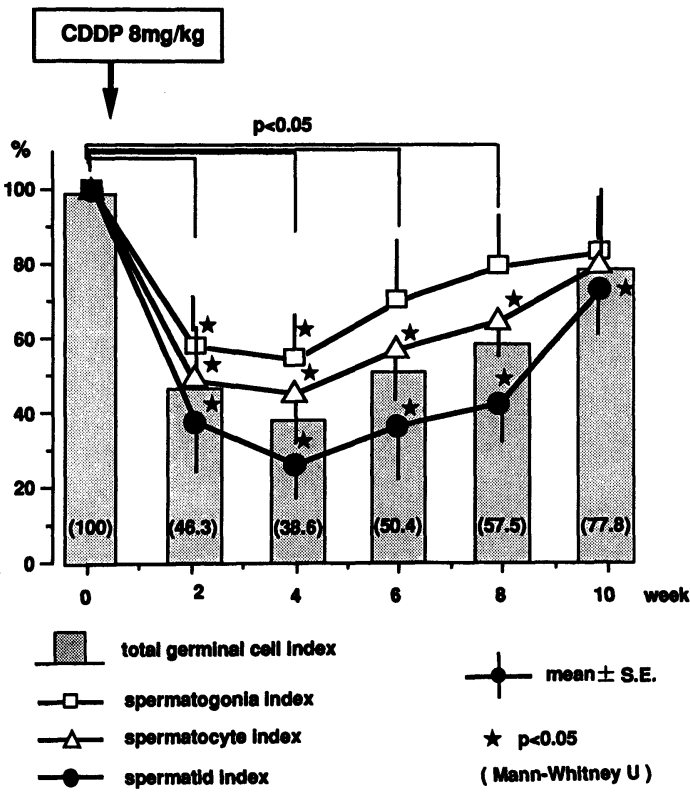

Fig. $2 \mathrm{~b}$ Effect of CDDP $4 \mathrm{mg} / \mathrm{kg}$ on germinal cell index.

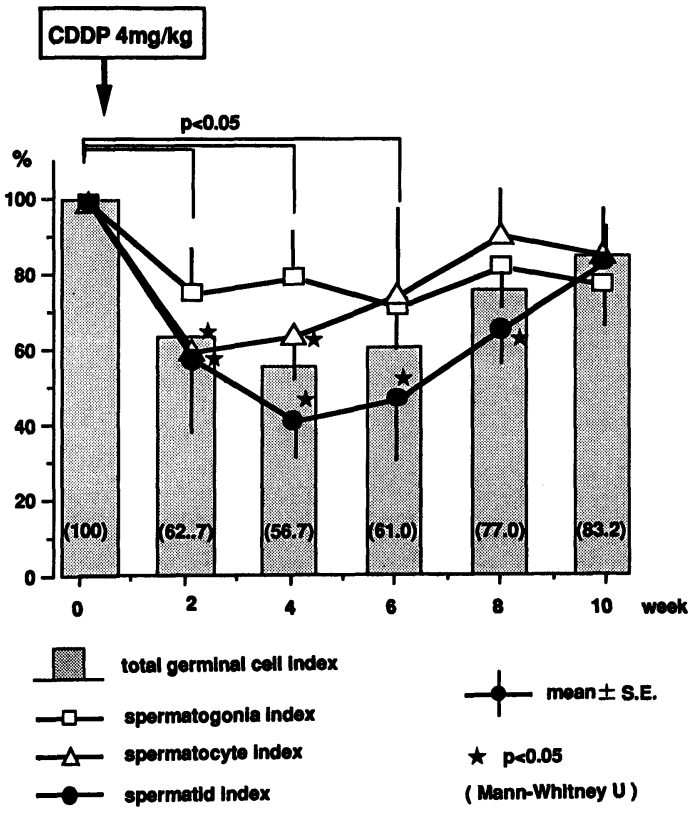

index のみが有意な低下を示した。

(1)-(b) Cyproterone acetate 投与群における精巣 の組織学的所見
Fig. 2c Effect of CDDP $2 \mathrm{mg} / \mathrm{kg}$ on germinal cell index.
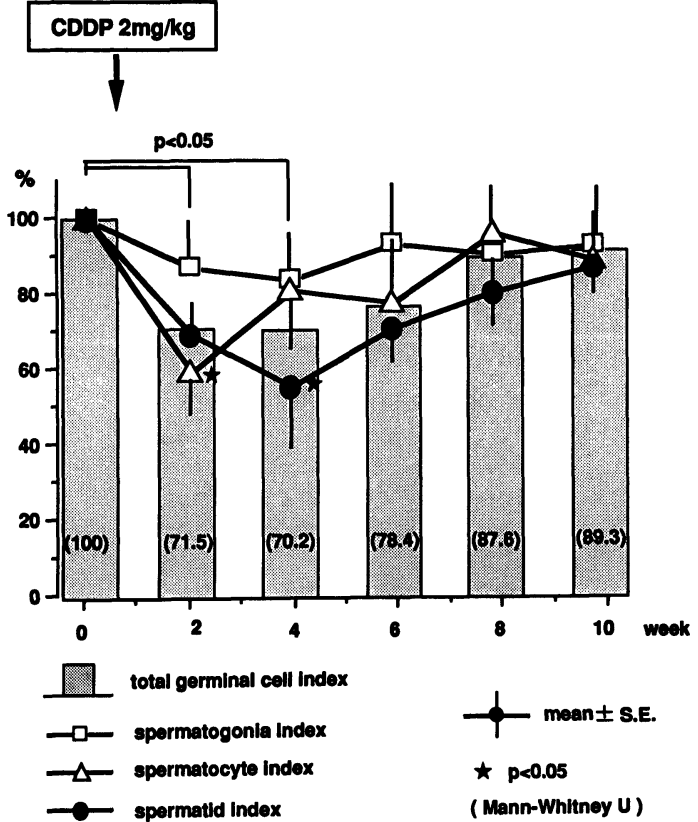

Cyproterone acetate $30 \mathrm{mg} / \mathrm{kg}, 15 \mathrm{mg} / \mathrm{kg}, 7.5 \mathrm{mg} /$ $\mathrm{kg}$ の投与後, 各 germinal cell index の推移をまとめ た Fig. 3a，b，cを見ると，次のような所見になってい る.

各投与群とも，CDDP 投与群にみられた所見とは異 なり spermatogonia, spermatocyte $の$ germinal cell index の低下があまり著しくないが，それにも拘わら ず spermatid index の低下は比較的顕著であるという 特徴が認められた。

(1)-(c) Flutamide 投与群における精巣の組織学的 所見

Flutamide $30 \mathrm{mg} / \mathrm{kg}, 15 \mathrm{mg} / \mathrm{kg}, 7.5 \mathrm{mg} / \mathrm{kg}$ 投与後 の germinal cell index の推移を Fig. $4 \mathrm{a}, \mathrm{b}, \mathrm{c}$ に示し た. Flutamide 投与群においても cyproterone acetate 投与群と同様, spermatogonia index, spermatocyte index の低下は少なく, spermatid index の低下が目立 つ.しかも spermatid index の最低值は，CDDP 投与 群で見られたように 4 週目ではなく 2 週目であり，む しろ 4 週目からは回復し始めている所見であった。

(1) - (d) Spermatogenic curveによる検討

以上の 3 薬剤の spermatogenesis に対する障害の 内容を, 別の立場からまとめたのが Fig. 5 である. 本 図は各精細胞の germinal cell index を plotし，それ 
Fig. 3a Effect of cyproterone acetate $30 \mathrm{mg} / \mathrm{kg}$ on germinal cell index.

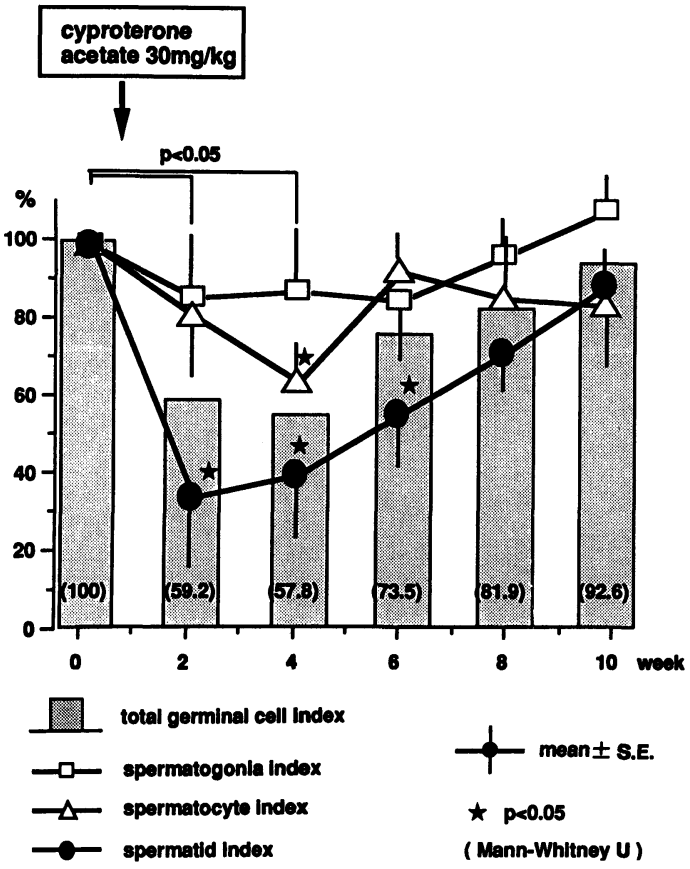

Fig. 3b Effect of cyproterone acetate $15 \mathrm{mg} / \mathrm{kg}$ on germinal cell index.
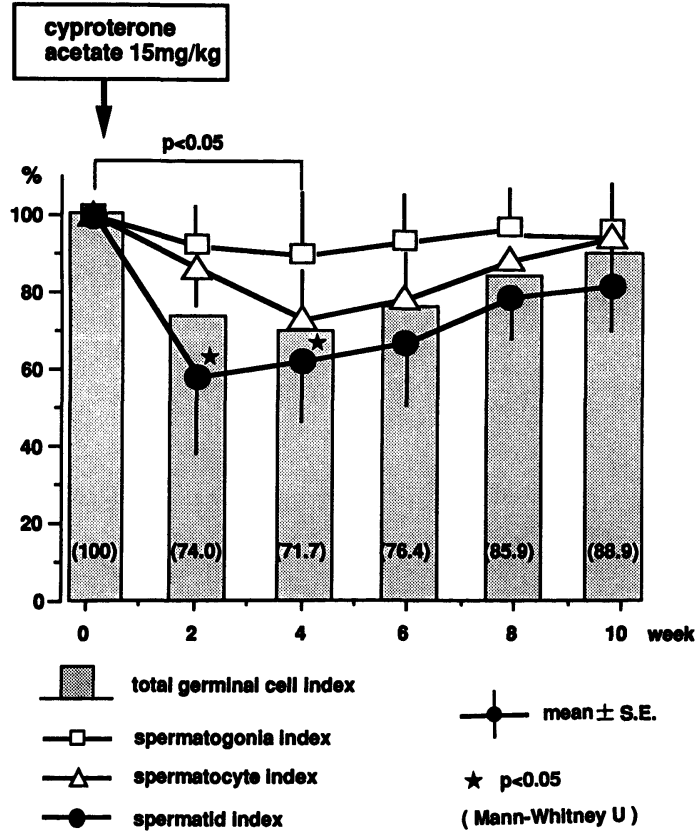

$\star p<0.05$

(Mann-Whitney U)
Fig. 3c Effect of cyproterone acetate $7.5 \mathrm{mg} / \mathrm{kg}$ on germinal cell index.

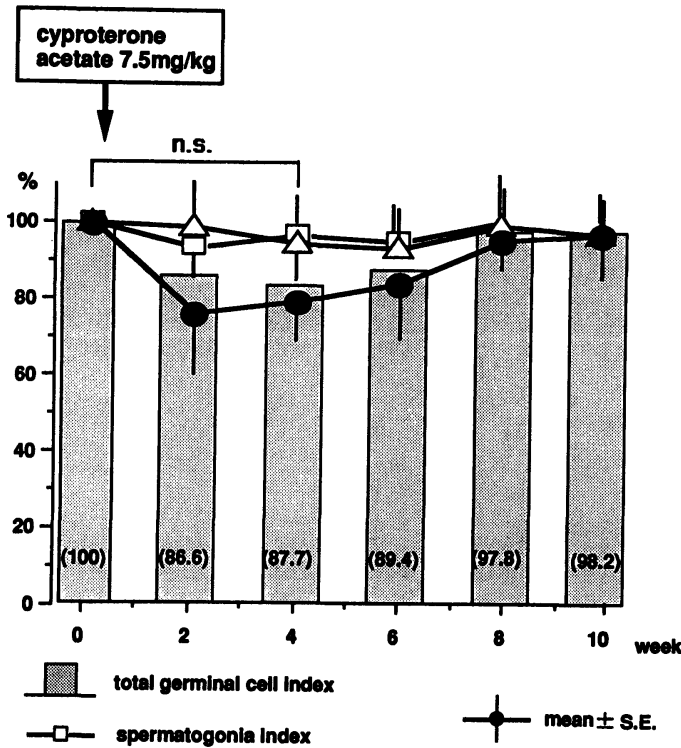

$\Delta-$ spermatocyto Index

n.s.

- spermatid index

( Mann-Whitney U)
Fig. 4a Effect of flutamide $30 \mathrm{mg} / \mathrm{kg}$ on germinal cell index.

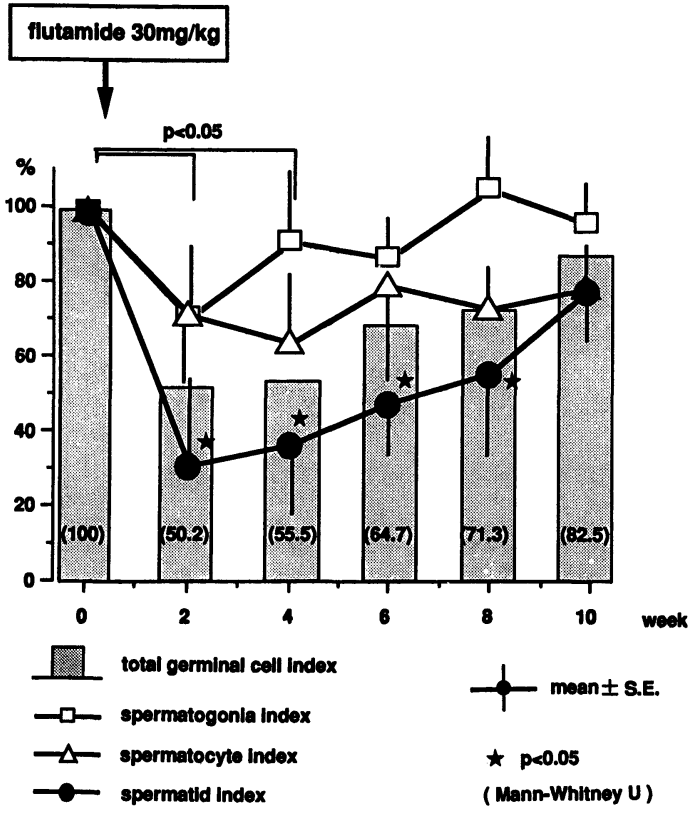


Fig. 4b Effect of flutamide $15 \mathrm{mg} / \mathrm{kg}$ on germinal cell index.
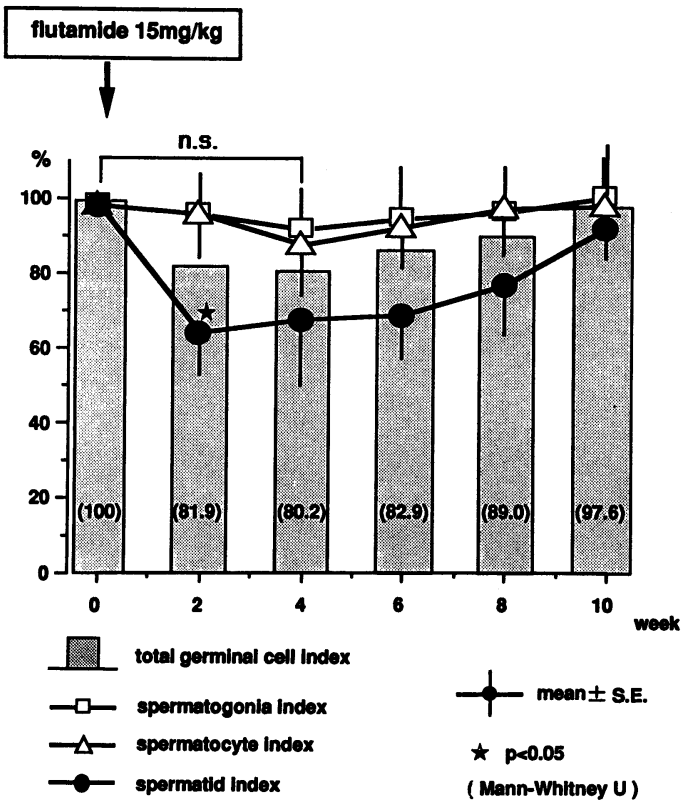

を線で結んだ spermatogenic curve $\mathrm{e}^{8)}$ を投与薬剤ごと にまとめた図である。

この図において最も特徴的な所見は，3 薬剤におけ る 2 週目での curve の所見（太線）である. CDDP 8 $\mathrm{mg} / \mathrm{kg}$ 投与群での curve は「下に凸」の形であり, spermatid と spermatocyte $の$ 細胞数比は 1.35 と 1 以
Fig. 4c Effect of flutamide $7.5 \mathrm{mg} / \mathrm{kg}$ on germinal cell index.

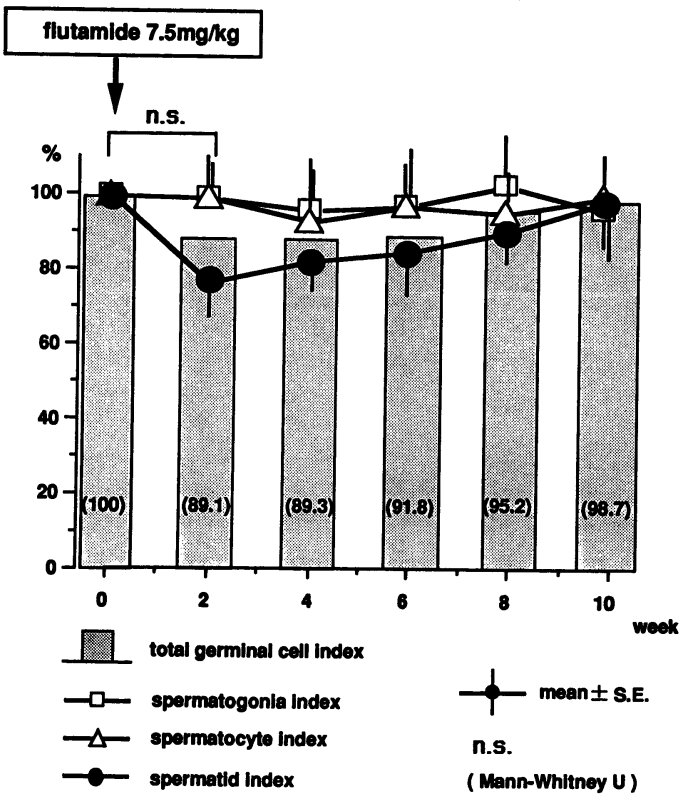

上であった.一方, cyproterone acetate $30 \mathrm{mg} / \mathrm{kg}$, flutamide $30 \mathrm{mg} / \mathrm{kg}$ 投与群では， 2 週目の時点でこの 細胞数比がそれぞれ $0.74 ， 0.73$ と 1 以下に低下し， curve は逆に「上に凸」の形であった。

この所見は抗 androgen 剤では急激な Sertoli 細胞 機能障害による，著しい spermatidの障害が先行した

Fig. 5 Spermatogenic curves of damaged rat testes induced by CDDP $8 \mathrm{mg} / \mathrm{kg}$,

cyproterone acetate $30 \mathrm{mg} / \mathrm{kg}$ and flutamide $30 \mathrm{mg} / \mathrm{kg}$.

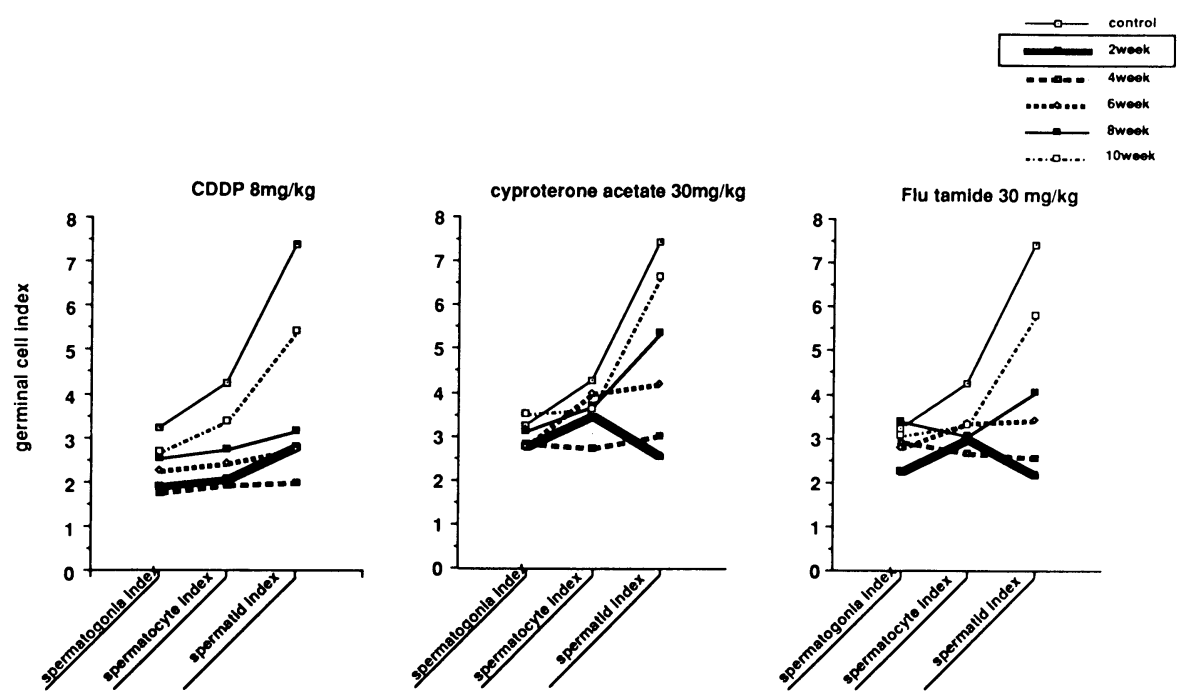


結果と考えられる.

\section{(小括 1 )}

以上， 3 種薬剤の投与後における germinal cell index の推移をまとめると, 抗癌剤である CDDP と, 抗 androgen 剤では変化のパターンに顕著な差が示さ れていた.

CDDP は spermatogonia をはじめ, spermatocyte および spermatid の 3 細胞群ともにある程度平行し て投与量依存性に高度化する障害が見られたが，抗 androgen 剤投与群においては, spermatogenesis の細 胞分裂期を中心とした， spermatogonia および spermatocyteでの障害は比較的軽度であり, spermatogenesis の late stage である spermatidにおける 障害が顕著に認められた。

(2) Spermatogenesis 障害時の DNA 合成能の経時 的変化

そこでこのような精細胞障害発症の機序を明らかに するため，spermatogenesis における DNA 合成能障 害の程度を，PCNA labeling index の経時的変化にて 検討した。

(2)-(a) CDDP 投与群におけるDNA 合成能の経 時的変化

Fig. 6 に CDDP 投与群における DNA 合成能の経 時的変化を示した. $\mathrm{CDDP}$ 投与群では $8 \mathrm{mg} / \mathrm{kg}, 4 \mathrm{mg} /$ $\mathrm{kg}, 2 \mathrm{mg} / \mathrm{kg}$ の全投与量群で有意な低下が認められ， しかもほぼ投与量に比例して障害度が高度化する所見 が示されている.また,すべて 2 週目を nadir として低

Fig. 6 Effect of CDDP on PCNA labeling index index.

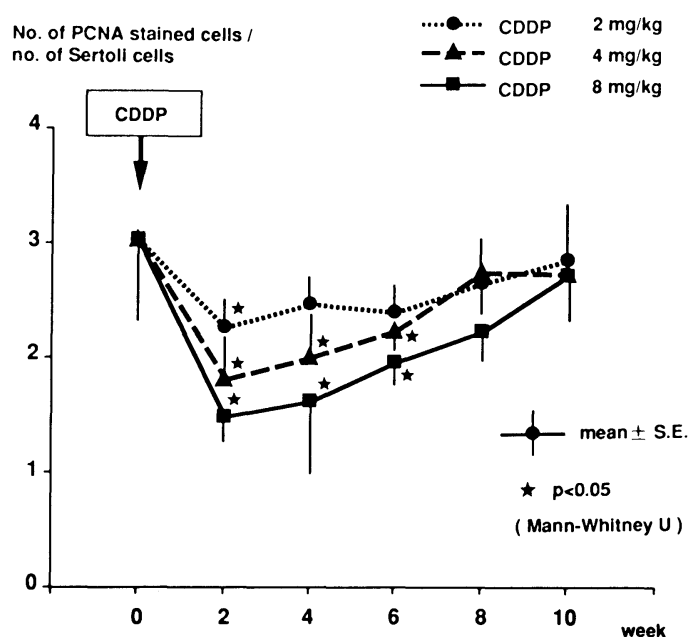

下し，徐々に10週目に向け回復傾向を示していた。

(2) - (b) 抗 androgen 剂投与群における DNA 合成 能の経時的変化

Cyproterone acetate 及び flutamide 投与群におい ては, 両群とも $30 \mathrm{mg} / \mathrm{kg}$ 投与群では有意な低下がみら れたが， $15 \mathrm{mg} / \mathrm{kg} ， 7.5 \mathrm{mg} / \mathrm{kg}$ 投与群では有意な障害 は認めなかった(Fig. 7，8)。前項の組織学的所見で示

Fig. 7 Effect of cyproterone acetate on PCNA labeling index index.

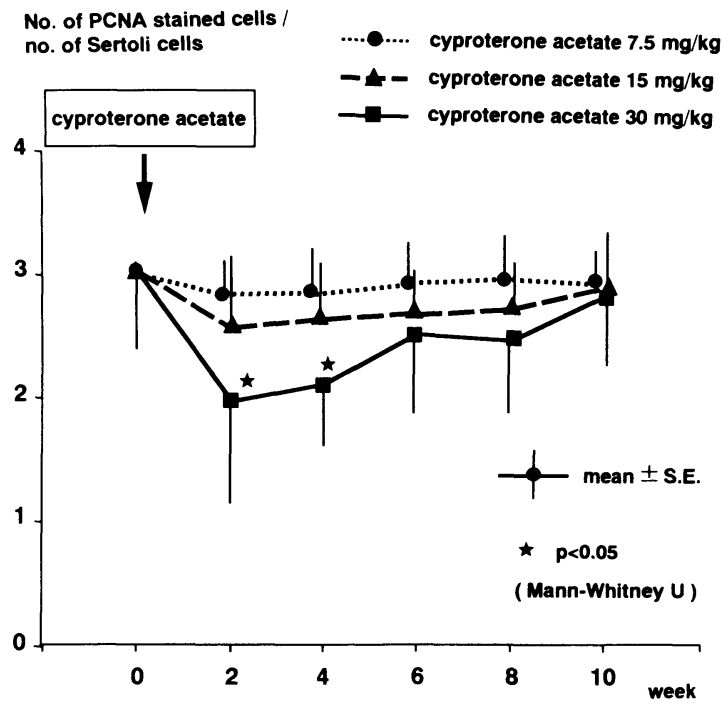

Fig. 8 Effect of flutamide on PCNA labeling index index.

No. of PCNA stained cells /

no. of Sertoli cells

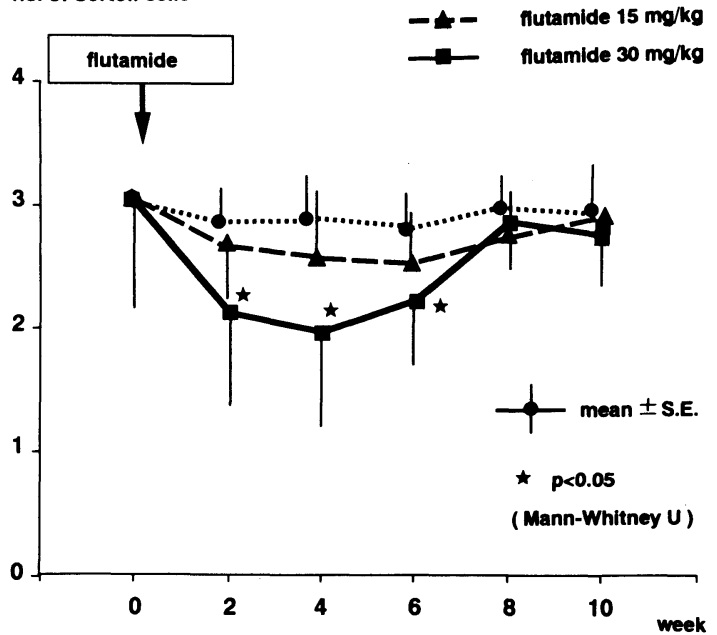


された spermatidの著しい障害にも拘わらず $15 \mathrm{mg} /$ $\mathrm{kg}, 7.5 \mathrm{mg} / \mathrm{kg}$ の低投与量群では DNA 合成能障害は ほとんど出現しないという所見となっていた。

\section{(小括 2)}

PCNA labeling indexによる spermatogenesisで の DNA 合成能の検討結果，CDDP では $8 \mathrm{mg} / \mathrm{kg}$ の高 投与量では勿論のこと, $4 \mathrm{mg} / \mathrm{kg}, 2 \mathrm{mg} / \mathrm{kg}$ の低投与量 群でも，2 週目において有意な低下を示し, DNA 合成 能の強い障害が認められた.一方, 抗 androgen 剤では ともに $30 \mathrm{mg} / \mathrm{kg}$ の高投与量では DNA 合成能障害を 認めたが, 低投与量群では DNA 合成能は障害されず, CDDP との顕著な違いであった。

（3） Spermatogenesis 障害時の Sertoli 細胞機能 次に spermatogenesis 障害発現のもう一つの原因 と考えられる, Sertoli 細胞機能障害を検討してみた。 Sertoli 細胞機能の生化学的指標のひとつである transferrin 産生能を精巣組織内 transferrin 濃度で検討し たのが Fig. 9〜11 である.

(3) - (a) CDDP 投与群の精巣組織内 transferrin 濃 度の経時的変化

CDDP 投与群での推移を示した Fig. 9 をみると， 8 $\mathrm{mg} / \mathrm{kg}$ 投与群では著しい transferrin 濃度の低下がみ られ，4 週目に最低となり，その後10週に向けて回復 した.しかし $4 \mathrm{mg} / \mathrm{kg}, 2 \mathrm{mg} / \mathrm{kg}$ 投与群では transferrin 濃度の低下は軽度であり, 先に検討した PCNA labe-

Fig. 9 Effect of CDDP on testicular transferrin concentration.

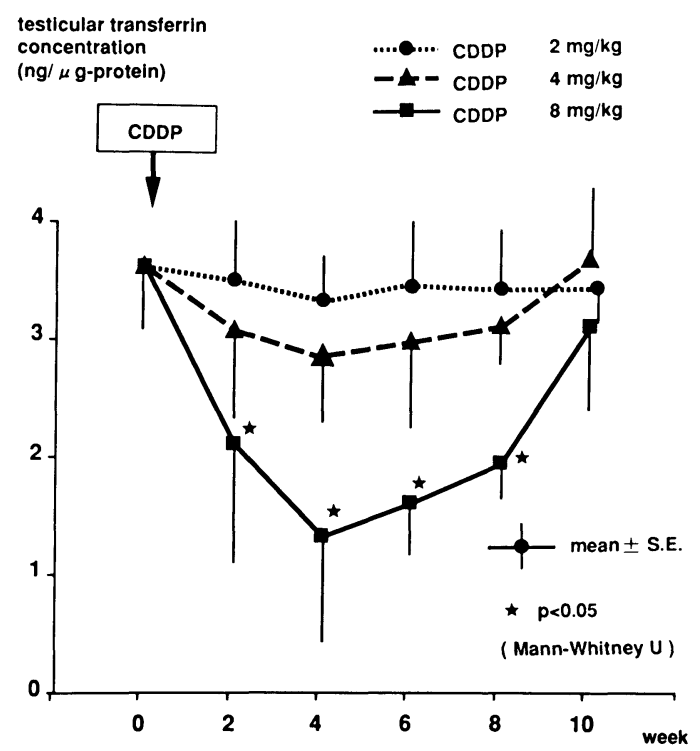

ling index のような，薬剤投与量に平行した curve の 動きとは異なる所見であった。

(3) - (b) Cyproterone acetate 投与群の精巣組織内 transferrin 濃度の経時的変化

Cyproterone acetate 投与後の精巣組織内 transferrin 濃度の推移を見ると, 各投与量群の transferrin 濃 度は，容量依存性に障害を受け，3 投与群ともに同様

Fig. 10 Effect of cyproterone acetate on testicular transferrin concentration.

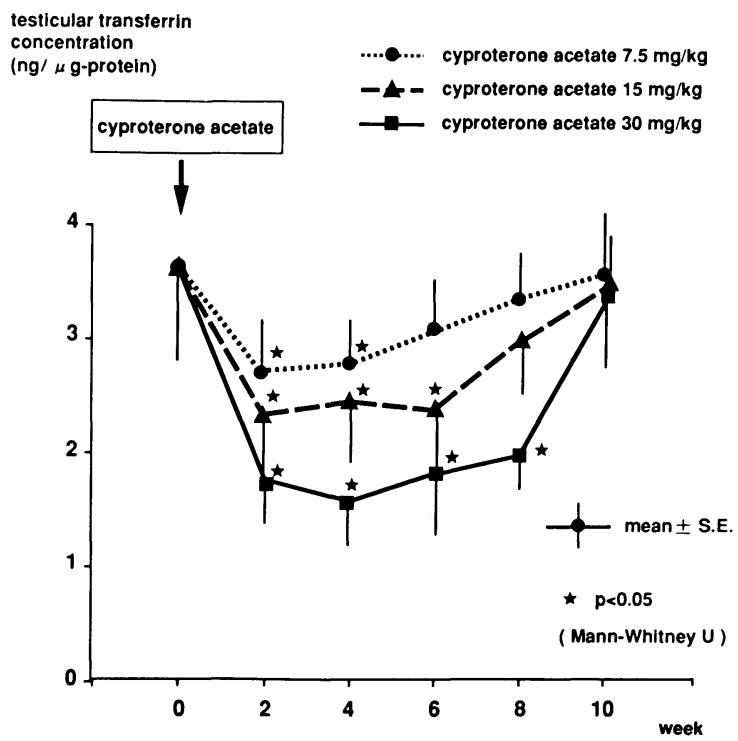

Fig. 11 Effect of flutamide on testicular transferrin concentration.

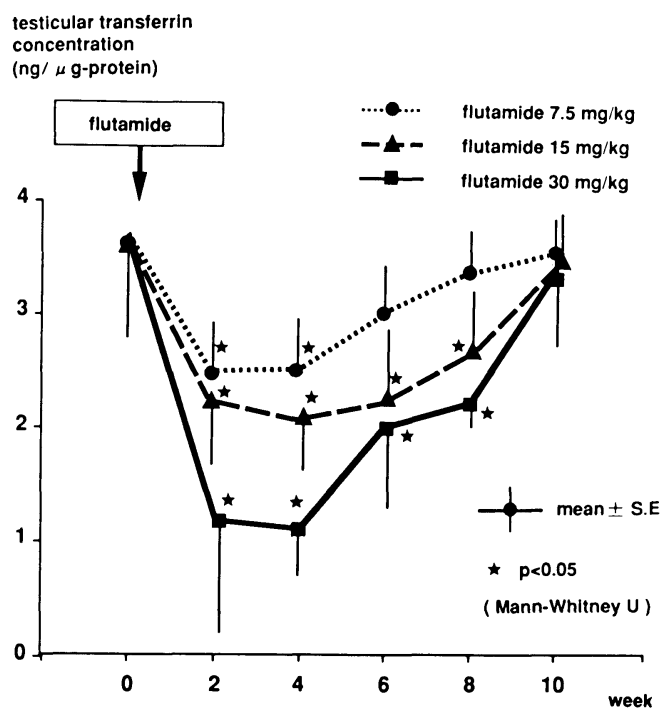


な回復経過を示していた（Fig. 10）.

(3)-(c) Flutamide 投与群の精巣組織内 transferrin 濃度の経時的変化

Flutamide 投与群の所見でも $30 \mathrm{mg} / \mathrm{kg}, 15 \mathrm{mg} / \mathrm{kg}$, $7.5 \mathrm{mg} / \mathrm{kg}$ の推移はFig. 11 に示したごとく, cyproterone acetate 投与群同様, 比較的容量依存性の 障害で進行した。

(小括 3 )

精巣組織内 transferrin 濃度による Sertoli 細胞機 能の検討結果では, 抗癌剤と抗 androgen 剤での所見 の差異は, 前項の PCNA labeling index による DNA 合成能と反対の結果を示していた。すなわち, 高投与 量群では, 両薬剂ともに Sertoli 細胞機能の障害が認 められたが, 低投与量群では抗癌剤では Sertoli 細胞 機能障害を認めず, 逆に抗 androgen 剤投与群では, 低 投与量群でも有意に Sertoli 細胞機能障害が発現する という結果であった。

\section{考 察}

抗癌剤の薬理作用は主として DNA 合成能障害にあ り，抗癌剤による spermatogenesis 障害の発現機序 も, その DNA 合成能障害によることは推定される。今 回の実験で使用したCDDPは, 腫瘍細胞の分裂時 （DNA 合成時）に細胞の DNA との間に DNA-蛋白と の結合 (DNA-protein cross links), おょびDNA 鎖 間架橋（interstrand cross-links）を形成することによ り抗腫瘍効果を発現する ${ }^{13)}$.

抗癌剤による spermatogenesis 障害の実験的研究 も，主としてその DNA 合成能障害の観点からの報告 が多い.

$\mathrm{Lu} ら^{14)}$ は，7種類の抗癌剤をマウスに投与し，これ らの薬剤が spermatogoniaに対し，細胞障害 (cell death）を発症させることを組織学的に示した。また Mistrich ら ${ }^{15}$ は, 抗癌剤による spermatogonia への障 害は, 薬剤の種類により spermatogoniaにおける細胞 分裂時の障害パターンが異なることを示した。CDDP ではA2-typeの spermatogonia から B-type の spermatogoniaでの細胞分裂を特に強く障害することを 報告している.

このような光顕による組織学的研究のみならず, Vawda ${ }^{16)}$ は, 実際に精細胞の thymidine の取り込 み能を検討し, CDDPによる spermatogenesis 障害が DNA 合成能の障害であることを示した。

また，これとは別に Sertoli 細胞機能障害という観 点から, Pogach ら ${ }^{17)}$ はラットの血清および精巣組織
中の androgen-binding-protein (ABP) を測定し, $\mathrm{CDDP} 10 \mathrm{mg} / \mathrm{kg}$ の大量投与により血清中の ABP 濃 度が低下したことから, Sertoli 細胞機能障害の発症を 推定している.しかし ABP の測定については, 今だ一 定の評価は得られてなく, また血中濃度の低下のみで Sertoli 細胞機能障害を推定するには検討を要すると ころである.

一方，同様に spermatogenesis 障害をもたらす抗 androgen 剤に関しての研究として, Flickinger ら ${ }^{18)}$ はラットに cyproterone acetateを投与し, 電顕にて Sertoli 細胞内に多くの脂肪滴の出現を認め, 形態的な Sertoli 細胞機能の障害発症を推定している. そして同 時に認めた late stage の spermatid の顕著な脱落は, その Sertoli 細胞機能の低下によると説明している.

馬場ら ${ }^{19}$ は，摘出したラット精巣の灌流実験で cyproterone acetate が testosterone の分泌能の低下 を来たすことを示し，直接 Leydig 細胞機能が影響を 受けていると報告した。

Cyproterone acetateの抗 androgen 剂作用は主に 中枢での gonadotropin 抑制にあるが，主に末梢性に 抗 androgen 剤作用を示す flutamide での研究では Chandolia ら ${ }^{5}$ は, flutamideによる障害精巣において 精巣の間質機能が低下し, spermatogenesis 障害が発 症するとしている.

このように薬剤による spermatogenesis 障害の研 究は個々の薬剤での検討が多く, 作用機序の異なる薬 剤の障害を同じ方法において評価し，その相違点の比 較研究は行われていなかった。そこで著者らは，特に CDDP の spermatogenesis 障害の特徵を, 抗 androgen 剂での障害と比較し検討した。

今回の検討結果から，抗 androgen 剂である cyproterone acetate や flutamide では $30 \mathrm{mg} / \mathrm{kg}$ の高 投与量のみならず，低投与量群でも精巣組織内 transferrin 濃度の有意な低下が認められ, Sertoli 細胞機能 への抑制作用が示された. 組織学的にもSertoli 細胞 機能障害の反映とされる, spermatid 数の低下が特に 顕著にみられており，これらは理論的にも合致する所 見と云える.

一方，抗癌剤 (CDDP) による spermatogenesis 障 害は DNA 合成能への直接的な障害が主体であると考 えられた. ただ CDDP $8 \mathrm{mg} / \mathrm{kg}$ の高投与量群において は精巣組織 transferrin 濃度も有意な低下があり, Sertoli 細胞機能の障害も同時に認めた。

これは CDDP は投与量が多ければ強い細胞毒性を 
発現し, Sertoli 細胞に障害を及ぼした結果と推定され た。そして Sertoli 細胞機能低下が起きれば, spermatogenesis 初期の DNA 合成を行っている spermatogonia や spermatocyte も代謝障害が起き, 精細 管内 DNA 合成能低下の別の一要因となっている可能 性もある。

すなわち CDDP $8 \mathrm{mg} / \mathrm{kg}$ の高投与量群においては spermatogenesis 障害の発現機序として, 直接的な DNA 合成能障害の他に, Sertoli 細胞機能を介した DNA 合成能障害の両者の関与が考えられた.

$$
\text { ところでラットに扔ける CDDP } 8 \mathrm{mg} / \mathrm{kg} \text { という投 }
$$

与量は, ヒトではおよそ $54 \mathrm{mg} / \mathrm{m}^{2}$ になる7).精巣腫瘍に 対する多剤併用化学療法一PVBでは, CDDP の投与 量は 1 回 $20 \mathrm{mg} / \mathrm{m}^{2}$ 6) であり, 通常は 5 日間連日静脈内 投与される. 投与方法は異なるが，投与量としては桁 違いに高い量ではなく, 臨床的にもこの CDDPによる Sertoli 細胞機能障害は充分に発現しうると考えられ る.

今後, 抗癌剂の spermatogenesis 障害予防や治療に おいて, 今回の検討は基礎的研究として意義のあるも のと考える.

\section{文 献}

1）古武敏彦,三木恒次 : 睪丸腫瘍の治療と現況。癌と 化学療法, 15, 195-204, 1987.

2) Thachill, J.V., Jewett, M.A.S. and Rider, W.D. : The effects of cancer and cancer therapy on male fertility. J. Urol., 126, 141-145, 1981.

3) Berthelesen, J.G. and Skakkebaek, N.E. : Gonadal function in men with testis cancer. Fertil. Steril., 39, 68-75, 1983.

4) Huhtaniemi, I., Parvinen, M., Venho,P. and Rannikko, S.: Combination of a GnRH agonist with an antiandrogen or bromocriptine in the treatment of prostatic cancer; slight potention of antigonadal effects. Int. J. Androl., 14, 374-386, 1991.

5) Chandolia, R.K., Weinbauer, G.F., Fingscheidt, U., Bartlett, J.M. and Nieschlag, E. : Effects of Flutamide on testicular involution induced by an antagonist of gonadotropin-releasing hormone and on stimulation of spermatogenesis by follicle-stimulating hormone in rats. J. Reprod. Fertil., 93, 313-323, 1993.

6) Einhorn, L.H. and Donahue, J.: Cisdiamminedichlorophatinum, vinblastin and bleomycin combination chemotherapy in disseminated testicular cancer. Ann. Int. Med., 87, 293-298, 1977.

7) Freireich, E.J., Gehan, E.A., Rall, D.P., Schmidt,
L.H. and Skipper, H.E. : Quantitative comparison of toxicity of anticancer agents in mouse, rat, hamster, dog, monkey, and man. Cancer Chemotherapy Reports, 50, 219-245, 1966.

8）熊本悦明, 伊藤直樹, 丸田 浩, 南部明民：Spermatogenesis 障害精巣の病理学的所見の検討一わ れわれの障害判定法（市川・熊本分類および ger minal cell index) の臨床的意義について一. 病理 と臨床，7，296-306，1989.

9) Leblond, C.P. and Clermont, Y.: Definition of the stages of the cycle of the seminiferous epithelium of the rat. Ann. N.Y. Acad. Sci., 55, 548-573, 1952.

10) Skinner, M.K. and Fritz, I.B. : Androgen stimulation of Sertoli cell function is enhanced by peritubular cells. Mol. Cell Endocrinol., 40, 115 $-122,1985$.

11) Bradford, M.M. : A rapid and sensitive method for the quantitation of microgram quantities of protein utilizing the principle of protein-dye binding. Anal. Biochem., 72, $248-$ 254, 1976.

12) Skinner, M.K., Cosand, L. and Griswold, M.D. : Purification and characterization of testicular transferrin secreted by rat Sertoli cells. Biochem. J., 218, 313-320, 1984.

13) Plooy, A.C.M., van Dik, M. and Lohman, P.H. M. : Induction and repair of DNA cross-links in Chinese hamster ovary cells treated with various platinum coordination compounds, in relation to platinum binding to DNA, cytotoxicity, mutagenicity, and antitumor activity. Cancer Res., 44, 20543-2051, 1984.

14) $\mathrm{Lu}$, C.C. and Meistrich, M.L.: Cytotoxic effects of chrmotherapeutic drugs on mouse testis cells. Cancer Res., 39, 3575-3582, 1979.

15) Mistrich, M.L.: Stage-specific sensitivity of spermatogonia to different chemotherapeutic drugs. Biomed. Pharmacotherapy, 38, 137-142, 1984.

16) Vawda, A.I. and Davis, A.G.: Effects of cisplatin on mouse testis. Acta Endocr., 112, 436441, 1986.

17) Pogach, L.M., Lee, Y., Gould, S., Giglio, W., Meyehofer, M. and Huang, H.F.S. : Characterization of cis-platinum induced Sertoli cell dysfunction in rodents. Toxicol. Apple. Pharmacol., 98, 350-361, 1989.

18) Flickinger, C.J. and Loving, C.K.: Fine structure of the testis and epididymis of rats treated with cyproterone acetate. Am. J. Anat., 146, 359-384, 1976.

19）馬場志郎：Cyproterone Acetate のラット辠丸機 能に及ほす効果. 日泌尿会誌, 73, 636-643, 1982. (1994年9月5日受付，12月12日受理） 